\begin{tabular}{|l|l|l|}
\hline \multicolumn{2}{|c|}{ PublisherInfo } \\
\hline \hline PublisherName & $:$ & BioMed Central \\
\hline \hline PublisherLocation & $:$ & London \\
\hline \hline PublisherImprintName & $:$ & BioMed Central \\
\hline \hline
\end{tabular}

\title{
Is RNA inheritance possible?
}

\begin{tabular}{|l|l|l||}
\hline \multicolumn{2}{|c|}{ ArticleInfo } \\
\hline \hline ArticleID & $:$ & 5072 \\
\hline \hline ArticleDOI & $:$ & $10.1186 /$ gb-spotlight-20050324-01 \\
\hline \hline ArticleCitationID & $:$ & spotlight-20050324-01 \\
\hline \hline ArticleSequenceNumber & $:$ & 48 \\
\hline \hline ArticleCategory & $:$ & Research news \\
\hline ArticleFirstPage & $:$ & 1 \\
\hline \hline ArticleLastPage & $:$ & 3 \\
\hline \hline & & RegistrationDate : 2005-3-24 \\
\hline ArticleHistory & $:$ & OnlineDate \\
\hline \hline ArticleCopyright & $:$ & BioMed Central Ltd2005-3-24 \\
\hline \hline ArticleGrants & $:$ & \\
\hline \hline ArticleContext & $:$ & 130596611 \\
\hline \hline
\end{tabular}


Evidence for inheritance based on RNA has been found in a particularly unstable plant gene, researchers suggest in Nature this week. Robert Pruittand colleagues at Purdue University in West Lafayette, Ind., found that Arabidopsis plants homozygous for recessive mutant alleles of particular gene may inherit genomic information that is not found in the parent plant, but that existed in earlier generations.

"We can imagine two parallel pathways, one of DNA-based inheritance, and in the background you have this other which might be RNA - or an odd form of DNA-based inheritance we don't understand," Pruitt told The Scientist.

Pruitt's team was investigating HOTHEAD, a gene responsible for organ fusion and wax cuticle production. Previous researchhas shown unusual point mutation instability in the gene in Arabidopsis, which results in a high frequency of wildtype plants from mutant parents.

In the latest study, Pruitt's team used polymerase chain reaction to determine that $10 \%$ of the progeny of mutant plants revert to wildtype, and those plants were heterozygous for the parent's mutant HOTHEAD (hth) allele.

Measuring directly in pollen, they also found a strong bias for wildtype changes in the plant's male reproductive system - seen from the creation of dominant allele $(\mathrm{HTH} / \mathrm{HTH})$ wildtype progeny when the male parent plant, not the female parent, was a homozygous mutant.

The progeny of mutants, Pruitt said, bypass their parents' DNA mutations by some undetermined mechanism, and the allelic reversions restore the original DNA sequence of the grandparent plant.

"In this study, you have the fascinating proposal that in the rare cases when a DNA mutation occurs, RNA descending from previous generations can lend a hand to assist its superior, more privileged cousin," David Bartel from the Massachusetts Institute of Technology told The Scientistin an E-mail. Bartel was not involved in the current study.

Pruitt's group also looked at randomly chosen polymorphisms in F3 generation progeny from crossed mutant plants homozygous for HOTHEAD and found evidence of genetic instability for all sequence polymorphisms across the genome.

After tests that found three more independent reversion events within three different mutant hth alleles, a high rate of random mutation was ruled out. Data strongly suggested that the genetic changes were the result of a template-driven process, the authors write.

"We've looked for a DNA template fairly carefully and can't find one, so then by exclusion, we say it's probably a type of stable RNA," said Pruitt. However, the phenomenon has only been found in mutants because "in the wildtype individual, the contribution of this secondary pathway for inheritance is probably negligible," Pruitt told The Scientist. 
Pruitt and his coauthors note that their RNA template hypothesis is supported by recent work showing that double-stranded RNA can be transmitted for many generations in Caenorhabditis elegans.

Why mutant progeny revert back to wildtype is unknown, but the authors suggest that stress linked to the hth gene may be involved. "With the theory of stress, it's possible that rather than introducing random mutations into the DNA, this unknown process kicks in, which potentially reverts alleles back to successful alleles of past generations," said John Bowman, from University of California at Davis, who was not involved in the study.

Speculating on the implications of a RNA-based inheritance, plant geneticist Detlef Weigel of the Max Planck Institute for Developmental Biology in Germany told The Scientist, "If there were some cache of RNA, I would still think of the DNA as the dominating form. [Possibly] the genome has this kind of fail-safe mechanism to make use of stored RNA. It's not presently clear."

Continuing their work, Pruitt and colleagues will now focus on which genes are most directly involved in the process of sequence change and biochemically identify the location of the putative templates.

\section{References}

1. S.J. Lolle, et al., "Genome-wide non-mendelian inheritance of extra-genomic information in Arabidopsis," Nature, 434:505-09, March 24, 2005., [http://www.nature.com]

2. Robert E. Pruitt, [http://www.btny.purdue.edu/Faculty/Pruitt/]

3. K.A. Krolikowski et al., "Isolation and characterization of the Arabidopsis organ fusion gene HOTHEAD," Plant J,35:501-11, August 2003.

4. David P. Bartel, [http://www.wi.mit.edu/research/faculty/bartel.html]

5. A. Fire et al., "Potent and specific genetic interference by double-stranded RNA in Caenorhabditis elegans," Nature, 391:744-5, February 19,1998.

6. John L. Bowman, [http://biosci.ucdavis.edu/BioSci/FacultyAndResearch/

DisplayFacultyProfile.cfm?ResearcherID=1507]

7. Detlef Weigel, [http://www.weigelworld.org/research] 